OPTIMUM. ECONOMIC STUDIES NR 2 (92) 2018

\author{
Piotr PODSIADLO, PhD \\ Faculty of Finance and Law, Cracow University of Economics \\ e-mail: piotr.podsiadlo@uek.krakow.pl
}

DOI: 10.15290/oes.2018.02.92.08

\title{
GRANTS AND TAX SUBSIDIES AS THE MAIN FORMS OF STATE AID - A PERSPECTIVE OF THE STATE OF PUBLIC FINANCE*
}

\begin{abstract}
Summary
State aid according to Article 107 par. 1 TFEU brings economic advantage to certain enterprises or productions of certain goods, excluding others. In other words, the given measure cannot be regarded as State aid, if it does not bring any benefits to the addressed entity. State aid may therefore be described as the selective increment of financial benefits to an enterprise or a group of enterprises, which at the same time is accompanied by formation of a financial burden on the side of public finances. This burden may be in the form of public spending to enterprises or reducing the regulatory burdens imposed on the enterprises. In the first case it will be aid provided by active support mechanisms, such as grants, interest rate subsidies on bank credits, refunds, preferential and conditionally discharged loans, sureties, and credit guarantees. In the second case it will be the aid provided by tax exemptions and tax deferrals (tax subsidies), the conversion of enterprise debt to capital, or postponing the payment of specific public contributions.

The subject of the article is to present the conditions of admissibility of State aid in the European Union. This should lead to verify the hypothesis of the influence of State aid on the state of public finance in EU Member States which provided State aid in the form of grants and tax subsidies in the years 2000-2016. This analysis is carried out based on the linear regression model. The response variable (dependent variable $\mathrm{Y}$ ) is the size of the general government sector debt, and explanatory variable (independent variable $X$ ) is state aid in the form: 1) grants; 2) tax exemptions and tax deferrals. In the other words, the hypothesis highlights that State aid in the form of grants and tax subsidies, in respect to the whole European Union and particular Member States, should be positively correlated with the size of the general government sector debt.

Results: The conducted analysis of regression indicated that State aid in the form of grants and tax subsidies (tax exemptions + tax deferrals) and the size of the general government sector debt are linearly dependent - respectively regarding 22 and 14 Member States, which in the years 2000-2016 provided State aid in these forms.
\end{abstract}

Key words: State aid, the European Union, grants, tax subsidies, general government sector debt

JEL: E62, K20, K33

\footnotetext{
* The publication was financed from means granted to the Faculty of Finance of Cracow University of Economics, in the framework of subsidy to keep the research capacity.
} 


\section{Introduction}

Modern European economies rely heavily on markets and private enterprises to decide what goods to make and sell, what capital projects to fund, what innovations to undertake, and where all these activities should take place. There are many reasons for this, from the belief that competitive markets are an important protector of liberty, to more economic concerns with efficiency. Modern European economies do not, however, rely on markets and private enterprises for everything, and do not leave markets and enterprises completely free from interference and regulation. This is not surprising. Markets, after all, do not always deliver efficient outcomes. In any case governments often pursue goals that have nothing to do with economic efficiency, and spend large amounts on a wide variety of policies [Bacon, 2009, p. 9]. For example, governments are often directly involved in the provision of public services such as health services, education, social welfare, national defense, law and order, and environmental protection. Governments also play an active role in managing important sectors of the economy, often where the sector is dominated by a former State monopoly, such as in telecoms or energy. Governments may also regulate markets for a variety of other reasons, such as the need to manage systemic risks in the financial sector. State aid is thus just one of many channels through which governments have an impact on the functioning of markets and economies. It is, however, probably the channel that is most tightly regulated under EU law.

Basic regulations of competition law on State aid can be found in Articles 107, 108, and 109 of the Treaty on the Functioning of the European Union [TFEU, 2016]. Article 107 establishes EU regulations regarding state aid admissibility. The provisions of Article 107 par. 1 TFEU establish a principle of general prohibition of granting State aid and the provisions of par. 2 and 3 allow for granting State aid by way of exemption from the general prohibition. These exceptions are respectively the categories of aid which are admissible as compatible with the internal market (art. 107, par. 2) and the categories of aid which may be permitted or may be considered compatible with the internal market principles (art. 107, par. 3). Article 108 defines the powers of the Council and the European Commission with regard to the aid granted by Member States and compliance with the provisions of art. 107. In turn Article 109 gives the Council the power to issue regulations establishing rules for the application of art. 107 and 108 [Podsiadło, 2016, pp. 771-781].

State aid within the meaning of Article 107 par. 1 TFEU causes advantage for certain enterprises or the production of certain goods, excluding others [Nicolaides, 2013, pp. 271-290]. In other words, a given measure cannot be regarded as State aid if it does not bring any benefits to the entity to which it is addressed. The advantage may take various forms associated with the phrasing of Article 107 par. 1 TFEU, which states explicitly that the aid may be provided in "any form". The European Commission applies in practice the 
division of forms of State aid into four groups [European Commission, 2001] Group A includes those aid instruments, the use of which results in the transfer of the total amount of aid to the recipient. This group is divided into two subgroups, where A1 is aid provided directly from the budget (grants, refunds), and A2 is aid provided by the tax system or the social security system (tax exemptions and reliefs, reductions of social security contributions). Group B covers the forms of capital commitment of the country in the capital of the enterprises, subject to the exception where the state acts as a private investor (private investor test). The subgroup B1 (provision of capital to an enterprise) and subgroup B2 (converting enterprise debt into capital) can be specified here. Group $C$ is the transfer of funds in which the value of aid is equal to the interest which the beneficiary does not have to pay for the period during which the given capital remains at its disposal. Within this group there are also two subgroups specified, i.e. C1 comprises so-called soft credit instruments (loans and preferential credits) and C2 includes tax deferral and other obligatory payments of a public law character. The last group D comprises active aid in the form of sureties and guarantees provided by the public authorities.

The subject of the article is to present the conditions of admissibility of State aid in the European Union. This should lead to verifying the hypothesis of the influence of State aid on the state of public finance in EU Member States which provided State aid in the form of grants and tax subsidies in the years 2000-2016. This analysis is carried out based on the linear regression model. The response variable (dependent variable $\mathrm{Y}$ ) is the size of the general government sector debt, and explanatory variable (independent variable $\mathrm{X}$ ) is State aid in the form of: 1) grants; 2) tax exemptions and tax deferrals. In other words, the hypothesis highlights that State aid in the form of grants and tax subsidies, in respect to the whole European Union and particular Member States, should be positively correlated with the size of the general government sector debt.

\section{Economic justification for State aid in the European Union}

In the market of the European Union, which is based on the mechanism of free competition, many changes occur as a result of the impact of micro-, meso- and macroeconomic factors. On the one hand, these changes go together with positive effects in the form of the development of enterprises, both those already operating in the Internal market as well as those whose strategic goal is to enter the market and do business activity in the long term. Compliance with the principles of free competition, reduction of entry barriers, elimination of customs barriers, consistent combating of monopolistic practices, the inflow of direct foreign investments and the related production increase, creating the conditions for public procurement, and suppliers' endeavour for uni- 
form purchase prices and purchasing products at prices adopted in the country where they are the lowest - these are the desired effects of competition in the Single European Market, enabling economic and social development of the European Union [Adamkiewicz-Drwiłło, 2010, p. 58]. On the other hand, not all market processes can be considered as the desired effect of competition. Then it is indicated that a market economy, in which the primary regulator of the occurring processes is competition, is burdened with certain deficiencies. The deficiencies of the market system are, in such a situation, justification for a replacement or supplement based on free competition of the market mechanism by other decision-making processes, such as State intervention.

The existence of market inefficiencies makes the assumptions on which the model of perfect competition is made, not always fulfilled, and thus it becomes difficult to achieve overall balance as well as maximize total prosperity. In other words, the lack of optimal market efficiency in the Pareto sense may justify state interventionism with the object of ensuring the optimal allocation of resources. Therefore, market inefficiencies justify State intervention and legitimize public authorities to adopt specific legal, administrative, and economic regulations within the scope of aid for enterprises; however, it is important to remember such balancing of the size of provided aid so the negative consequences do not bring more harm to entities functioning in the market. The actions taken by the State aimed at correcting market failures within the scope of the intervention in economic processes can also be ineffective due to the probability of government failures [Tunali, Fidrmuc, 2015, pp. 1143-1162]. At this point the failure of the State is shown, associated with its role as a remedy to the problem of information asymmetry and coordination of supply and demand, which means that state actions to encourage improvements in the efficiency and allocation of market mechanisms are subject to failure and as a result can lead, just like a market mechanism, to inefficient allocation of resources [Demsetz, 1969]. This means that State intervention in the economy is basically justified only in the occurrence of market imperfections, even when there is no guarantee that the measures used by the State will lead to greater prosperity, which is due to the lack of possession by the public authorities of the necessary information or high cost of the use of appropriate measures of aid [Crafts, 2017, pp. 105-112]. However, even if the State has the necessary information and relevant financial resources and intervenes in order to promote market mechanisms and economic growth, the control of these interventions cannot be avoided at the supranational level [Botta, Schwellnus, 2015, pp. 335-352]. This is because even legitimate actions taken by a given State within the interference in economic processes can cause harmful side effects in other countries [Nicolaides, 2004, pp. 365-396]. Hence, due to the impact that the provided aid has on the economic interests of enterprises that are beneficiaries, and also their competitors and the economy of individual countries, the issues relating to the 
admissibility of the aid are precisely regulated within the European Union. The rules adopted at the EU level affect the national regulations that relate to the provision of aid itself [Veebel, Ploom and Kulu, 2015, pp. 50-64]. They answer the question of whether the aid designed by a Member State, legal in the light of its national law, may be considered as compatible with the objectives of the European Union and whether it can be given. These principles are addressed to Member States and are designed to eliminate aid which has a negative impact on competition and trade within the Internal market and in cases where such aid must be exceptionally provided, the discipline of those countries and standardizing of conditions within the EU that must be fulfilled in order for aid to be provided, which in turn should minimize its negative effects.

\section{Grants and tax subsidies - general rules and statistics}

The foundation of European Union policy in the area of State aid is the notation in Article 107 par. 1 of the Treaty on the functioning of the European Union, according to which State aid is inconsistent with the Internal market. Article 107 par. 1 TFEU states that: "Subject to other provisions foreseen in the Treaties, any aid provided by a Member State or by means of State resources in any form, which disturbs or threatens to disturb the competition by favouring of certain enterprises or the production of certain goods shall be inconsistent with the Internal market within the scope as it affects the trade between Member States". In the application of the competition rules of the European Union in the field of State aid, it is not significant if the instrument used is a fiscal measure, because Article 107 par. 1 TFEU applies to aid measures "in any form". A fiscal measure from a group of tax subsidies can be referred as aid within the meaning of Article 107 par. 1 if it fulfils the cumulative criterion, which consists of four elements [Podsiadło, 2015, pp. 103-120].

Firstly, the measure must give the recipients of aid economic benefit that will consist of advantages which release them from burdens that are normally taken from their budgets. These privileges may be provided by reducing the tax burdens on the enterprises in a variety of ways, such as:

- reduction in the tax base (such as special deductions, special or accelerated adaptation of depreciation, or introducing reserves in the balance sheet),

- total or partial reduction in the amount of tax (exemption from tax payment or a tax credit),

- remission of tax liability or even abandonment of tax collection.

Secondly, the benefit must be granted by the State or from public funds. The loss of tax revenues is equivalent with the consumption of State resources in the form of financial expenses, even when the public support can be provided by both the tax provisions of a legislative, executive, or administrative nature, or through the practices of the tax authorities. 
Thirdly, the measure must affect the competition and trade between Member States. This rule assumes that:

- the aid recipient performs an economic activity involving trade between Member States,

- the received aid strengthens the position of an enterprise compared with the position of other enterprises which are competitors in trade in the Single European Market.

Fourthly, the measure must fulfil the criterion of selectivity, which should be understood as promoting selected enterprises, sectors of the economy, regions of the country, or specific products. In addition, State aid concerns only those enterprises which, due to the criterion of profitability, would not be funded by private investors, aiming in the long term for return of the invested capital plus a reasonable profit. The public authorities providing aid in a given field aim to realize specific economic and social objectives. So State aid means financial support from public funds in such situations when the involvement of private funds is not economically justified.

State aid instruments used by Group A are characterized by the transfer of the total provided support in such a way that the amount of aid provided is equal to the transfer of funds from individual budgets. The State aid in this case can be provided either directly from the budget or at the expense of the budget. The aid from the budget, which means the instruments of A1 Group, are primarily grants, reductions in interest rates on bank credits, refunds, and export bonuses. Member States granted aid in the form of grants of about $€ 634.33$ billion in 2000-2016: EU-15 - €566.74 billion, EU-13 - only €67.59 billion [Eurostat, 2018a]. The largest amounts of State aid have been granted by Germany (€198.26 billion), France (€100.55 billion), Italy (€61.22 billion), Spain (€48.73 billion) and United Kingdom (€44.47 billion). In the Central and Eastern Europe area the countries that provided the greatest State aid in the form of grants are Poland, Hungary, Czech Republic, and Romania - respectively €25.84 billion, $€ 11.88$ billion, €11.75 billion and €5.27 billion.

On the contrary, the aid causing the depletion of budget revenues - Groups $\mathrm{A} 2$ and $\mathrm{C} 2$ - is tax exemptions and relief, redemptions, postponement and rescheduling of tax collection, reduction in the amount of benefits in the social security system, omission of execution of para-budgetary debts and abandonment of collection of interest receivable for overdue public-legal liabilities, and tax deferral and other obligatory payments of a public law character. In this case, Member States granted aid in the form of tax subsidies of about $€ 387.82$ billion in 2000-2016: EU-15 - €353.18 billion, EU-13 - only €34.64 billion [Eurostat, 2018b]. The largest amounts of State aid have been granted by Germany (€109.88 billion), France (€83.33 billion), Sweden (€34.37 billion), United Kingdom (€33.07 billion) and Portugal (€22.26 billion). In the Central and Eastern Europe area the countries that provided the greatest State aid in the form of tax exemptions and tax deferrals are Poland, Hungary, Romania and Czech Republic - respectively €14.11 billion, €6.79 billion, €4.61 billion and €2.90 billion. 


\section{Problem formulation and methodology}

The level of general government sector debt is useful information not only in studying the sustainability of public finance resulting from the weight of burdens with service costs in the short term. It also shows the implementation of the redistribution-intergenerational function, where growing public debt in the current period may result in the instability of public finance for future generations. As a test period the years 2000-2016 were adopted, i.e. the period of implementation of the two most important development strategies of the European Union - the Lisbon strategy and the "Europe 2020" strategy (taking the year 2016 as the closing period of observation was due to the available annual data on State aid, which is published by Eurostat). The thesis was accepted that the amount of State aid provided by EU Member States in the form of grants and tax subsidies should be positively correlated with the size of general government sector debt of these countries. The response variable (dependent variable Y) is the size of general government sector debt, and the explanatory variable (independent variable $X$ ) is state aid in the form of: 1) grants; 2) tax exemptions and tax deferrals. The positive correlation of the size of general government sector debt with the amount of State aid in the form of grants and tax subsidies would mean that with the increase of such State aid there should be an increase in the debt of the public finance sector of EU Member States providing such aid.

Statistical analysis will be carried out based on two source tables.

The first table shows the calculations for the linear regression model concerning respectively the slope parameter (directional factor $(\beta)$. $t$ Stat is a test of linear relationship occurrence between expenditure on State aid in the form of grants and tax subsidies and the size of the general government sector debt. This statistical test allows one to verify the authenticity of the so-called null hypothesis that the parameter of the regression function I type $\beta$ is equal to zero, with the alternative hypothesis that it is not equal to zero $\left(H_{0}: \beta=0 ; H_{A}: \beta \neq 0\right)$. The acceptance of the null hypothesis that the parameter $\beta=0$ would mean that an increase in the value of expenditure on State aid by $€ 1$ million will not cause any changes in the size of the general government sector debt which means the lack of any relationship between expenditure on State aid and the size of the general government sector debt. In other words, the acceptance of the null hypothesis means the lack of the influence of State aid in the form of grants and tax subsidies provided by the Member States of the European Union on the size of their general government sector debt. From the perspective taken in this paper it will be essential to reject the null hypothesis in favor of an alternative hypothesis which states that between the studied phenomena - expenditure on State aid and the size of the general government sector debt - there is a significant statistical relationship. From the tables of critical values of $t$-Student it is seen that $\pm t_{\frac{\alpha}{2}}= \pm 2.1315$ for $\alpha=0.05$ and $n-2=15$ degrees of freedom. The null hypothesis can be rejected in favor of the alternative hypothesis only when $t_{b}<t_{\frac{\alpha}{2}}$ or $t_{b}>t_{\frac{\alpha}{2}}$; that is, when $-t_{b}<-2.1315$ or $+t_{b}>+2.1315$. 
The second table contains regression statistics. Among the regression statistics are: the correlation coefficient, determination coefficient, standard error and the parameters of the $\mathrm{F}$ test; that is, the value of the F-test and the probability of making a type I error, when the hypothesis is verified concerning the lack of impact of expenditure on State aid on the size of the general government sector debt (the irrelevance of State aid expenditure in the regression model). The Ftest, similarly as the described above t-test, is used for testing the significance of linear regression coefficient $\beta$ evaluation. The checking of this test is a statistic $F$ having F-Snedecor distribution of $k_{1}$ and $k_{2}$ freedom degrees. When rejecting the null hypothesis $F>F_{\alpha}$ of no relation between expenditure on State aid and the size of the general government sector debt and accepting the alternative hypothesis of the existence of a statistically significant relationship between the variables. From the table of critical values of the F-Snedecor for $k_{1}=1$ ( 1 independent variable) and $k_{2}=n-2=15$ degrees of freedom and $\alpha=0.05$ we read $F_{0.05}=$ 4.543. Thus, the alternative hypothesis can be adopted only when $F>4.543$.

\section{Grants and general government sector debt}

The most important statistical test in the simple regression analysis is a test of whether the regression coefficient equals zero. If in a specific case it could be concluded that the directional coefficient of the real regression line in the population equals zero, it would mean that between expenditure on State aid and the size of general government sector debt, there is no linear relation, or expenditure on State aid and the size of general government sector debt are not linearly dependent. Therefore, there should be a test of the linear relation occurrence between expenditure on State aid in the form of grants in the Member States and the size of their general government sector debt. Statistics on this test are shown in table 1.

TABLE 1

State aid in the form of grants and the size of general government sector debt the analysis of variance: the line "variable $X$ "

\begin{tabular}{|l|c|c|c|c|c|c|}
\hline $\begin{array}{c}\text { EU Member } \\
\text { States }\end{array}$ & $\begin{array}{c}\text { Regression } \\
\text { coefficient } \\
b\end{array}$ & $\begin{array}{c}\text { Standard } \\
\text { error } \\
S b\end{array}$ & $\begin{array}{c}t \text { Stat } \\
t b\end{array}$ & $p$-value & Lower 95\% & Upper 95\% \\
\hline Austria & 91.00832 & 26.62729 & 3.417858 & 0.003815 & 34.25358 & 147.763 \\
\hline Belgium & 262.2911 & 53.38253 & 4.913426 & 0.000187 & 148.509 & 376.0733 \\
\hline Bulgaria & 30.48924 & 8.025476 & 3.799057 & 0.001747 & 13.38334 & 47.59513 \\
\hline Cyprus & 169.5831 & 20.93137 & 8.101861 & $7.37 \mathrm{E}-07$ & 124.9689 & 214.1972 \\
\hline Czechia & 40.16887 & 5.551142 & 7.236145 & $2.9 \mathrm{E}-06$ & 28.33689 & 52.00085 \\
\hline Denmark & 29.17355 & 6.802818 & 4.28845 & 0.000647 & 14.67368 & 43.67341 \\
\hline
\end{tabular}




\begin{tabular}{|l|c|c|c|c|c|c|}
\hline $\begin{array}{c}\text { EU Member } \\
\text { States }\end{array}$ & $\begin{array}{c}\text { Regression } \\
\text { coefficient } \\
b\end{array}$ & $\begin{array}{c}\text { Standard } \\
\text { error } \\
S b\end{array}$ & $\begin{array}{c}t \text { Stat } \\
t b\end{array}$ & $p$-value & Lower 95\% & Upper 95\% \\
\hline Estonia & 10.74542 & 1.470355 & 7.308044 & $2.58 \mathrm{E}-06$ & 7.611432 & 13.87941 \\
\hline Finland & 155.4492 & 25.91937 & 5.997413 & $2.44 \mathrm{E}-05$ & 100.2034 & 210.695 \\
\hline France & 4.950036 & 23.15923 & 0.213739 & 0.833629 & -44.4127 & 54.31277 \\
\hline Germany & 14.93104 & 11.69036 & 1.277209 & 0.220945 & -9.98638 & 39.84846 \\
\hline Greece & 250.8682 & 66.77156 & 3.757112 & 0.001903 & 108.548 & 393.1884 \\
\hline Hungary & 29.0205 & 5.972617 & 4.858925 & 0.000208 & 16.29016 & 41.75083 \\
\hline Ireland & 342.8967 & 138.7612 & 2.471127 & 0.025941 & 47.13412 & 638.6593 \\
\hline Italy & -122.758 & 36.46336 & -3.3666 & 0.004238 & -200.478 & -45.0379 \\
\hline Latvia & 14.27963 & 3.861164 & 3.698271 & 0.002147 & 6.049754 & 22.50951 \\
\hline Lithuania & 84.44976 & 12.0076 & 7.033025 & $4.05 \mathrm{E}-06$ & 58.85617 & 110.0434 \\
\hline Malta & -49.1484 & 20.23431 & -2.42896 & 0.028181 & -92.2768 & -6.02001 \\
\hline Netherlands & 193.4921 & 35.59607 & 5.435771 & $6.89 \mathrm{E}-05$ & 117.6208 & 269.3633 \\
\hline Poland & 43.33196 & 8.154974 & 5.313563 & $8.68 \mathrm{E}-05$ & 25.95005 & 60.71388 \\
\hline Portugal & 76.63632 & 114.5018 & 0.669302 & 0.513474 & -167.419 & 320.6912 \\
\hline Romania & 71.26783 & 20.78536 & 3.428751 & 0.003731 & 26.96487 & 115.5708 \\
\hline Slovakia & 99.66185 & 21.97836 & 4.534544 & 0.000395 & 52.81608 & 146.5076 \\
\hline Slovenia & 73.82108 & 20.31938 & 3.633039 & 0.002454 & 30.51135 & 117.1308 \\
\hline Spain & -159.121 & 44.27609 & -3.59383 & 0.002659 & -253.493 & -64.7484 \\
\hline Sweden & 69.45252 & 90.46015 & 0.767769 & 0.454541 & -123.359 & 262.2638 \\
\hline UK & 378.3961 & 66.47953 & 5.69192 & $4.27 \mathrm{E}-05$ & 236.6984 & 520.0939 \\
\hline EU 28 & 126.7426 & 45.40691 & 2.791262 & 0.013699 & 29.96003 & 223.5251 \\
\hline
\end{tabular}

Source: own calculations.

On the basis of the calculations set out in table 1, it should be distinguished that the statistical basis for the recognition of the occurrence of a linear relation between expenditure on State aid and the size of general government sector debt exists in the case of 22 Member States. This relation occurs also at the level of the European Union (EU-28).

Only for three countries is there a negative relation between the variables analyzed. For Italy, Malta, and Spain regression coefficients are negative, which means that expenditure on State aid in the form of grants have a negative impact on general government sector debt in these countries. The increase in expenditure on state aid by $€ 1$ million comes together with a fall in the size of general government sector debt - respectively - with an average of $€ 122.76$ million, €49.15 million, and €159.12 million. Estimation errors are respectively $€ 36.46$ million, €20.23 million and €44.28 million. Taking into account however the confidence interval for the regression coefficient, it can be said with a prob- 
ability of $95 \%$ that the increase of granted aid for undertakings with $€ 1$ million will cause a fall in general government sector debt by the value of the interval (€45.04 million; €200.48 million) for Italy, (€6.02 million; €92.28 million) for Malta, and (€64.75 million, €253.49 million) for Spain. It should also be noted that the probability of type I error ( $\mathrm{p}$-value), involving the rejection of a true null hypothesis that, in the case of those countries providing State aid in the form of grants which do not significantly affect the size of the general government sector debt of the countries, is below the accepted level of significance, i.e. 0.05. The consequence is that the result of the study in relation to these countries may be considered important, and thus the null hypothesis can be rejected in favour of the alternative hypothesis.

In the case of 19 Member States, the regression coefficient takes a positive value. Consequently, the increase in expenditure on State aid by $€ 1$ million is accompanied by an increase in GDP per capita by average: €91.01 million (Austria), $€ 262.29$ million (Belgium), €30.49 million (Bulgaria), €169.58 million (Cyprus), $€ 40.17$ million (Czech Republic), €29.17 million (Denmark), €10.75 million (Estonia), €155.45 million (Finland), €250.87 million (Greece), €29.02 million (Hungary), €342.90 million (Ireland), €14.28 million (Latvia), €84.45 million (Lithuania), €193.49 million (Netherlands), €43.33 million (Poland), €71.27 million (Romania), €99.66 million (Slovakia), €73.82 million (Slovenia), and €378.40 million (United Kingdom). At the level of the EU-28 increase in the value of general government sector debt is: $€ 126.74$ million.

Occurrence of the linear relationship between expenditure on State aid in the form of grants in the above-mentioned Member States and the size of their general government sector debt is also confirmed by the $\mathrm{F}$ test parameters, i.e. the value of the F-test and the probability of type I error when the hypothesis is verified on the lack of impact of expenditure on State aid to the size of general government sector debt (the irrelevance of State aid expenditure in the regression model). For all the indicated countries (also at the level of the European Union) F-test values are higher than the applied critical value of 4.543 , and the probability of type I error is less than 0.05 . The calculations in this regard are presented in table 2.

In the case of Italy, Malta and Spain, the values of the correlation coefficient are included in the interval $(0.53 ; 0.68)$. These countries are characterized by the weak and medium negative relationship occurring between the amount of provided State aid and the size of their general government sector debt. Moreover, there can be no satisfactory adjustment of the regression line to the empirical data. The determination coefficients for these countries equal $0.43,0.28$, and 0.46 .

For Cyprus, Czech Republic, Estonia, Finland, and Lithuania the correlation indicators are very strong: $0.902213,0.881659,0.883587,0.840061,0.875962$, and the determination coefficients are: $0.813988,0.777322,0.780726,0.705703$, 0.76731 . Therefore, variations in general government sector debt in these countries were explained in $81.40 \%, 77.73 \%, 78.07 \%, 70.57 \%$ and $76.73 \%$ with 
TABLE 2

State aid in the form of grants and the size of general government sector debt regression statistics and F-test

\begin{tabular}{|c|c|c|c|c|c|}
\hline \multirow{2}{*}{$\begin{array}{c}\text { EU Member } \\
\text { States }\end{array}$} & \multicolumn{3}{|c|}{ Regression statistics } & \multicolumn{2}{|c|}{ Test $\mathrm{F}$} \\
\hline & $\begin{array}{l}\text { Correlation } \\
\text { indicator }\end{array}$ & $\begin{array}{l}\text { Determination } \\
\text { coefficient }\end{array}$ & $\begin{array}{l}\text { Standard } \\
\text { error }\end{array}$ & $\mathrm{F}$ & Significance $F$ \\
\hline Austria & 0.661678 & 0.437818 & 42812.32 & 11.68175 & 0.003815 \\
\hline Belgium & 0.785352 & 0.616778 & 39323.71 & 24.14176 & 0.000187 \\
\hline Bulgaria & 0.700261 & 0.490365 & 1984.233 & 14.43283 & 0.001747 \\
\hline Cyprus & 0.902213 & 0.813988 & 2108.227 & 65.64014 & 7.37E-07 \\
\hline Czechia & 0.881659 & 0.777322 & 9770.49 & 52.3618 & $2.9 \mathrm{E}-06$ \\
\hline Denmark & 0.742142 & 0.550775 & 10936.88 & 18.39081 & 0.000647 \\
\hline Estonia & 0.883587 & 0.780726 & 321.1139 & 53.40751 & $2.58 \mathrm{E}-06$ \\
\hline Finland & 0.840061 & 0.705703 & 15633.8 & 35.96897 & $2.44 \mathrm{E}-05$ \\
\hline France & 0.055103 & 0.003036 & 457905.7 & 0.045684 & 0.833629 \\
\hline Germany & 0.313184 & 0.098084 & 358924.7 & 1.631263 & 0.220945 \\
\hline Greece & 0.696288 & 0.484817 & 50440.89 & 14.11589 & 0.001903 \\
\hline Hungary & 0.781979 & 0.611491 & 11798.08 & 23.60915 & 0.000208 \\
\hline Ireland & 0.537882 & 0.289317 & 65590.04 & 6.10647 & 0.025941 \\
\hline Italy & 0.656045 & 0.430395 & 242852.3 & 11.33402 & 0.004238 \\
\hline Latvia & 0.690606 & 0.476936 & 2799.173 & 13.67721 & 0.002147 \\
\hline Lithuania & 0.875962 & 0.76731 & 2524.19 & 49.46345 & $4.05 \mathrm{E}-06$ \\
\hline Malta & 0.531312 & 0.282292 & 868.3136 & 5.899869 & 0.028181 \\
\hline Netherlands & 0.814421 & 0.663282 & 51578.98 & 29.5476 & $6.89 \mathrm{E}-05$ \\
\hline Poland & 0.808115 & 0.65305 & 33720.44 & 28.23395 & $8.68 \mathrm{E}-05$ \\
\hline Portugal & 0.170289 & 0.028998 & 63308.54 & 0.447965 & 0.513474 \\
\hline Romania & 0.662861 & 0.439385 & 16185.18 & 11.75633 & 0.003731 \\
\hline Slovakia & 0.760396 & 0.578202 & 8194.667 & 20.56209 & 0.000395 \\
\hline Slovenia & 0.684153 & 0.468066 & 7283.779 & 13.19897 & 0.002454 \\
\hline Spain & 0.680196 & 0.462666 & 217176.8 & 12.91559 & 0.002659 \\
\hline Sweden & 0.194453 & 0.037812 & 23412.81 & 0.58947 & 0.454541 \\
\hline UK & 0.826759 & 0.683531 & 338058 & 32.39795 & $4.27 \mathrm{E}-05$ \\
\hline EU 28 & 0.584679 & 0.34185 & 2071200 & 7.791141 & 0.013699 \\
\hline
\end{tabular}

Source: own calculations.

variations in expenditure on State aid in the form of grants, while the remaining $18.20 \%$ result from the impact of other factors. If the coefficient of determination takes values less than 0.5 , the regression explains only less than $50 \%$ of the variation in GDP per capita and predictions based on such a regres- 
sion model may be unsuccessful because the regression model explains then very little. This means that predictions can be created based on the Cyprus model, because the regression model is characterised by a good fit and is little burdened with the estimation error, which provides grounds for precise forecasting.

Belgium, Hungary, Netherlands, Poland, and United Kingdom are characterized by a strong positive correlation occurring between the amount of provided aid to undertakings and the size of general government sector debt - respectively $0.785352,0.781979,0.814421,0.808115$ and 0.826759 . In the case of all five countries, there is the possibility to speak of a satisfactory adjustment of the regression line to the empirical data. For example, in the case of United Kingdom, the coefficient of determination is 0.683531. This means that the variation in general government sector debt of United Kingdom has been explained in $68.35 \%$ with the volatility of the expenditure on State aid in the form of grants. The remaining $31.65 \%$ is the effect of random and non-random factors (other non-aid variables, the imprecise fit of a straight line to the empirical data etc.).

For all countries of the European Union (EU-28) between the amount of State aid in the form of grants and general government sector debt there is a positive correlation $(r=0.584679)$. However, the determination coefficient assumes lower values and amounts to 0.34185 . This means that there can be no satisfactory adjustment of the regression line to the empirical data.

\section{Tax subsidies and general government sector debt}

Table 3 presents the calculations for verifying the hypothesis, according to which State aid in the form of tax subsidies granted by the EU Member States State does not affect the size of general government sector debt in these countries.

On the basis of the calculations in table 3, it can be concluded that in the case of five Member States (Cyprus, Italy, Malta, Portugal, and Spain), the regression coefficient takes a negative value. Consequently, the increase in tax subsidies by $€ 1$ million is accompanied by a decrease in general government sector debt by average: €28.89 million, €364.42 million, €24.68 million, €58.87 million, and $€ 450.15$ million. Margin of error is: €9.09 million, €84.35 million, €7.99 million, $€ 9.47$ million, and €157.63 million. Bearing in mind however the confidence interval for the regression coefficient, it can be said with a probability of $95 \%$ that the increase of granted state aid in the form of tax subsidies by $€ 1$ million will cause a decrease of general government sector debt of: Cyprus from €9.52 million to €48.26 million, Italy from €184.64 million to €544.21 million, Malta from $€ 7.66$ million to $€ 41.7$ million, Portugal from $€ 38.67$ million to $€ 79.06$ million and Spain from €114.18 million to €786.12 million. It should also be noted that the probability of type I error ( $p$-value), involving the rejection of a true null hypothesis that, in the case of these five countries providing State aid in the 
TABLE 3

State aid in the form of tax subsidies and the size of general government sector debt - analysis of variance: the line "variable $X$ "

\begin{tabular}{|l|c|c|c|c|c|c|}
\hline $\begin{array}{c}\text { EU Member } \\
\text { States }\end{array}$ & $\begin{array}{c}\text { Regression } \\
\text { coefficient } \\
b\end{array}$ & $\begin{array}{c}\text { Standard } \\
\text { error } \\
\text { Sb }\end{array}$ & $\begin{array}{c}t \text { Stat } \\
t b\end{array}$ & $p$-value & Lower 95\% & Upper 95\% \\
\hline Austria & 182.0379 & 43.24369 & 4.209583 & 0.000758 & 89.86614 & 274.2096 \\
\hline Belgium & 115.0724 & 27.30602 & 4.214176 & 0.000751 & 56.87096 & 173.2738 \\
\hline Bulgaria & 21.69725 & 43.57223 & 0.497961 & 0.625733 & -71.1747 & 114.5693 \\
\hline Cyprus & -28.8895 & 9.088691 & -3.17862 & 0.006231 & -48.2615 & -9.51738 \\
\hline Czechia & 115.1403 & 33.38459 & 3.448905 & 0.00358 & 43.98272 & 186.2979 \\
\hline Denmark & 7.799537 & 7.123742 & 1.094865 & 0.290845 & -7.38436 & 22.98343 \\
\hline Estonia & 25.78951 & 10.32617 & 2.497491 & 0.024627 & 3.779804 & 47.79923 \\
\hline Finland & 83.45875 & 9.17477 & 9.09655 & $1.71 \mathrm{E}-07$ & 63.90319 & 103.0143 \\
\hline France & 146.1467 & 23.27823 & 6.278257 & $1.48 \mathrm{E}-05$ & 96.53031 & 195.763 \\
\hline Germany & 57.8124 & 41.76655 & 1.384179 & 0.186553 & -31.2109 & 146.8357 \\
\hline Greece & -178.748 & 109.2945 & -1.63548 & 0.122755 & -411.704 & 54.20724 \\
\hline Hungary & -29.7589 & 24.58658 & -1.21037 & 0.244864 & -82.164 & 22.64615 \\
\hline Ireland & -280.382 & 132.2363 & -2.12031 & 0.051063 & -562.237 & 1.473407 \\
\hline Italy & -364.424 & 84.34696 & -4.32053 & 0.000606 & -544.205 & -184.642 \\
\hline Latvia & 28.46233 & 59.32505 & 0.479769 & 0.638312 & -97.986 & 154.9107 \\
\hline Lithuania & 43.5565 & 37.96116 & 1.147396 & 0.26919 & -37.3558 & 124.4688 \\
\hline Malta & -24.679 & 7.98657 & -3.09006 & 0.007467 & -41.702 & -7.65603 \\
\hline Netherlands & 177.7342 & 227.073 & 0.782718 & 0.445975 & -306.26 & 661.7289 \\
\hline Poland & -16.0589 & 13.26063 & -1.21102 & 0.244622 & -44.3233 & 12.20543 \\
\hline Portugal & -58.8666 & 9.474769 & -6.21298 & $1.66 \mathrm{E}-05$ & -79.0616 & -38.6716 \\
\hline Romania & -6.94915 & 16.39936 & -0.42375 & 0.677765 & -41.9036 & 28.00527 \\
\hline Slovakia & -114.626 & 53.26669 & -2.15194 & 0.048098 & -228.162 & -1.09121 \\
\hline Slovenia & 201.4745 & 45.56749 & 4.421452 & 0.000495 & 104.3497 & 298.5993 \\
\hline Spain & -450.149 & 157.6267 & -2.85579 & 0.012025 & -786.122 & -114.176 \\
\hline Sweden & 11.32081 & 5.125873 & 2.208563 & 0.043184 & 0.395273 & 22.24635 \\
\hline UK & 529.9361 & 97.55308 & 5.432285 & $6.93 \mathrm{E}-05$ & 322.0066 & 737.8656 \\
\hline EU 28 & 331.4452 & 85.50949 & 3.876121 & 0.001492 & 149.186 & 513.7043 \\
\hline
\end{tabular}

Source: own calculations.

form of tax subsidies do not significantly affect the size of the general government sector debt of the countries, is below the accepted level of significance, i.e. 0.05. The consequence is that the result of the study in relation to these countries, may be considered important, and thus the null hypothesis can be rejected in favour of the alternative hypothesis. 
For Austria, Belgium, Czech Republic, Estonia, Finland, France, Slovenia, Sweden and United Kingdom the regression coefficients take positive values, which means that the tax subsidies have a positive impact on general government sector debt of these countries. This relation occurs also at the level of the European Union (EU-28).

The increase in tax exemptions and tax deferrals by $€ 1$ million is accompanied by a rise in general government sector debt - respectively - with an average of €182.04 million, €115.07 million, €115.14 million, €25.79 million, €83.46 million, €146.15 million, €201.47 million, €11.32 million, and €529.94 million. At the level of the EU-28 the increase in the size of general government sector debt is $€ 331.45$ million. For these countries the probability of making a type I error, connecting with the rejection of a real null hypothesis concerning lack of relation between the size of the State aid and the value of GDP, is very small and does not exceed the accepted level of significance of 0.05 . Identical request as to the proposed hypothesis can be obtained by analyzing the value of $\mathrm{F}$ test (17.72, 17.76, 11.89, 6.24, 82.75, 39.42, 19.55, 4.88, 29.51, and 15.02 for EU-28 level), and $\mathrm{F}$ significance (lower than 0.05). F test parameters and regression statistics for the studied relationship between the size of the State aid to promote risk capital and the value of GDP in the European Union countries are shown in table 4.

In the case of Portugal, one can speak of a strong correlation of State aid granted in the form of tax subsidies with the size of general government sector debt in a negative sense. The correlation indicator equals 0.84862 . This model has a good fit to the empirical data, because for Portugal the determination coefficient is 0.720155 . Therefore, variations in the size of general government sector debt in this country were explained in $72.02 \%$ with variations in tax exemptions and tax deferrals, while the remaining $27.98 \%$ result from the impact of other factors.

In the case of Cyprus, Italy, Malta, and Spain, the value of the correlation indicators are: $0.63441,0.744621,0.62367$, and 0.593471 . These countries are characterized by a weak and medium negative relationship occurring between the amount of provided State aid in the form of tax subsidies and the size of its general government sector debt. Moreover, there can be no satisfactory adjustment of the regression line to the empirical data. The determination coefficients equal $0.402476,0.55446,0.388964$, and 0.352207 .

For Finland the correlation indicator is very strong: 0.920078 and the determination coefficient is 0.846543 . Therefore, variations in general government sector debt in this country were explained in $84.65 \%$ with variations in State aid granted in the form of tax exemptions and tax deferrals, while the remaining $15.35 \%$ result from the impact of other factors. This means that the predictions can be created basing on the Finnish model, because the regression model is characterised by a satisfactory fit and is little burdened with the estimation error, which provides grounds for precise forecasting. 
TABLE 4

State aid in the form of tax subsidies and the size of general government sector debt - regression statistics and F-test

\begin{tabular}{|c|c|c|c|c|c|}
\hline \multirow{2}{*}{$\begin{array}{c}\text { EU Member } \\
\text { States }\end{array}$} & \multicolumn{3}{|c|}{ Regression statistics } & \multicolumn{2}{|c|}{ Test F } \\
\hline & $\begin{array}{c}\text { Correlation } \\
\text { indicator }\end{array}$ & $\begin{array}{l}\text { Determination } \\
\text { coefficient }\end{array}$ & $\begin{array}{l}\text { Standard } \\
\text { error }\end{array}$ & $\mathrm{F}$ & Significance $F$ \\
\hline Austria & 0.735916 & 0.541573 & 38660.31 & 17.72059 & 0.000758 \\
\hline Belgium & 0.736284 & 0.542114 & 42984.06 & 17.75928 & 0.000751 \\
\hline Bulgaria & 0.127523 & 0.016262 & 2756.784 & 0.247965 & 0.625733 \\
\hline Cyprus & 0.63441 & 0.402476 & 3778.549 & 10.1036 & 0.006231 \\
\hline Czechia & 0.665037 & 0.442274 & 15462.79 & 11.89495 & 0.00358 \\
\hline Denmark & 0.272032 & 0.074001 & 15702.42 & 1.19873 & 0.290845 \\
\hline Estonia & 0.541942 & 0.293701 & 576.3148 & 6.23746 & 0.024627 \\
\hline Finland & 0.920078 & 0.846543 & 11289.26 & 82.74722 & $1.71 \mathrm{E}-07$ \\
\hline France & 0.851087 & 0.724348 & 240777.9 & 39.41651 & $1.48 \mathrm{E}-05$ \\
\hline Germany & 0.336546 & 0.113263 & 355891.6 & 1.915952 & 0.186553 \\
\hline Greece & 0.389016 & 0.151333 & 64739.71 & 2.67478 & 0.122755 \\
\hline Hungary & 0.298289 & 0.088977 & 18066.57 & 1.465 & 0.244864 \\
\hline Ireland & 0.480208 & 0.2306 & 68245.85 & 4.495703 & 0.051063 \\
\hline Italy & 0.744621 & 0.55446 & 214782.3 & 18.66699 & 0.000606 \\
\hline Latvia & 0.122936 & 0.015113 & 3841.012 & 0.230178 & 0.638312 \\
\hline Lithuania & 0.284053 & 0.080686 & 5017.243 & 1.316518 & 0.26919 \\
\hline Malta & 0.62367 & 0.388964 & 801.191 & 9.548483 & 0.007467 \\
\hline Netherlands & 0.198092 & 0.03924 & 87125.78 & 0.612648 & 0.445975 \\
\hline Poland & 0.298436 & 0.089064 & 54639.16 & 1.466577 & 0.244622 \\
\hline Portugal & 0.84862 & 0.720155 & 33986.85 & 38.60116 & $1.66 \mathrm{E}-05$ \\
\hline Romania & 0.108761 & 0.011829 & 21488.25 & 0.17956 & 0.677765 \\
\hline Slovakia & 0.485691 & 0.235896 & 11029.5 & 4.630825 & 0.048098 \\
\hline Slovenia & 0.752221 & 0.565837 & 6580.428 & 19.54924 & 0.000495 \\
\hline Spain & 0.593471 & 0.352207 & 238456.5 & 8.155558 & 0.012025 \\
\hline Sweden & 0.495366 & 0.245387 & 20734.12 & 4.87775 & 0.043184 \\
\hline UK & 0.814245 & 0.662995 & 348853.9 & 29.50972 & 6.93E-05 \\
\hline EU 28 & 0.707393 & 0.500405 & 1804548 & 15.02432 & 0.001492 \\
\hline
\end{tabular}

Source: own calculations.

In the case of France and United Kingdom, one can speak of a strong correlation of state aid granted to companies with the size of their general government sector debt in a positive sense: 0.851087 and 0.814245 . These models have a good fit to the empirical data, as its calculated coefficient of determination 
is 0.724348 and 0.662995 . Therefore, variations in general government sector debt in these countries were explained in $72.44 \%$ and $66.30 \%$ with variations in tax subsidies, while the remaining $27.56 \%$ and $33.70 \%$ result from the impact of other factors.

In the case of Austria, Belgium, Czech Republic, Estonia, Slovenia, and Sweden, the values of the correlation coefficient are included in the interval (0.495366; 0.752221). These countries are characterized by a weak or medium positive relationship occurring between the amount of provided State aid in the form of tax subsidies and the size of their general government sector debt. Moreover, there can be no satisfactory adjustment of the regression line to the empirical data. The determination coefficients for these countries equals from 0.245387 to 0.565837 .

For all countries of the European Union (EU-28) between the amount of State aid in the form of tax subsidies and general government sector debt there is a positive correlation $(\mathrm{r}=0.707393)$. However, the determination coefficient assumes lower values and amounts to 0.500405 . This means that there can be no satisfactory adjustment of the regression line to the empirical data.

\section{Discussion}

The concept of state intervention carried out by fiscal policy has developed quite rapidly and gained new supporters till the seventies of the twentieth century, that is, until in many economies the phenomenon of stagflation was observed. The effectiveness of interventions recommended by the supporters of the Keynesian trend was significantly weakened when, developing rapidly up till then, the economies of Western countries fell into stagnation, reflected by the minimum rate of economic growth, an increase in unemployment, and high inflation [Owsiak, 2006, pp. 63-64]. "Just as the Great Depression caused doubting in the mechanisms of the free market and liberalism, so stagflation of the early seventies led to a retreat from Keynesian economics and the rebirth of classical ideas" [Godłów-Legiędź, 2005, p. 557]. The then existing so-called oil crisis, which caused deep structural changes in the economies of individual countries, gave rise to criticism of State intervention carried out by fiscal policy, the effect of which was to be the violation of market mechanisms, undermining the laws governing the market and the destruction of the economy's resources. The monetarist revolution at the political level meant a return to the ideals of classical liberalism - to a free-market system with the limited role of the State in the economy. Objections raised to the idea of economic regulation, however, did not entirely negate the concept of state intervention, but led to a shift of impact on the economy from fiscal instruments to monetary instruments. As the State was accused of increasing the budget deficit and public debt, which were the factors causing inflation, monetarists gathered around M. Friedman recognized as a funda- 
mental issue the regulation of the money supply, mainly through indirect instruments, such as interest rates, exchange rates, or required reserves rates. Monetarism as a determination of macroeconomic doctrine became a point of reference for most of the discussion on the role of the state in the economy and, consequently, in the eighties and nineties of the twentieth century in the economic policy of highly developed countries free market trends began to dominate.

At the beginning of the twenty-first century there was a return to the need for State intervention in economic processes. Essential in this range was the position of the European Commission, whose task is to exercise control over compliance with European rules relating to the Member States' intervention in the economy [Botta, 2016, pp. 265-278; Pisapia, 2015, pp. 45-64]. A special role is played here by rules on granting State aid because their violation can lead to distortions of competition in the internal market. The European Commission, which has a wide range of competence in the field of State aid in this situation, had to settle the approach of applying the rules of aid admissibility of the Member States. This was essential, because the concept of aid is not defined in more detail in Article 107 par. 1 TFEU. Rather, its definition must be deduced from the elements set forth in that provision [Maurici, Sargent, 2015, pp. 621-643]. The prevailing opinion unanimously assumes in this connection that the concept of aid covers the granting of an advantage in the broadest sense of the term - "in any form whatsoever" - and therefore a broader area then the concept of a subsidy. While the concept of a subsidy only includes the positive granting of an advantage by the State, i.e. some additive benefit in cash or in kind - the concept of aid extends to the reduction of a financial burden. A reduction or exemption from taxes or social security contributions can therefore contain aid to the same extent as grants, investment of capital, granting of loans, delivery of goods or provisions of services [Nicolaides, Metaxas, 2014, pp. 51-60]. Hence, State measures which "mitigate the charges which are normally included in the budget of an enterprise and which, without therefore being subsidies in the strict meaning of the word, are similar in character and have the same effect", likewise constitute aid under long-standing case law of the EU Courts [Biondi, 2013, pp. 1719-1743; Baumane, Vodolagins, 2017, pp. 231-245]. It does not matter whether and to what extent the reduction in charges payable by the enterprise, for instance the tax concession or other benefit granted to an enterprise preparing to make an investment, is ultimately advantageous or disadvantageous to the finances of the affected public budget [Nicolaides, 2015, pp. 573-586]. The sole decisive factor is whether the State grants an economic advantage to a specific enterprise [Micheau, 2015, pp. 323348]. The Commission and the Courts have viewed in particular the legislative exemption from or deferral of taxes or security contributions as State aid [Milhet, 2017, pp. 1433-1452]. Aid is also deemed present where the State administration remains inactive and fails to collect promptly, or at all, taxes which are owed by a particular enterprise. 


\section{Conclusions}

From the economic point of view relating to state interventionism it ought to be noted that State aid can be a justified action mainly because of the social prosperity if free competition market mechanisms do not bring satisfactory results. In this case, a well-planned state intervention may improve the allocation of production factors, reduce the irregularity in market functioning and enable the achievement of common interest. The major criterion for providing State aid should be rationality, which is the highest determinant of the admissibility of using aid measures. It results from the fact that in a market economy competition is essential for the proper functioning of the market and protecting the interests of its participants. State aid should not violate it unless its violation will be compensated by positive market phenomena caused by providing the aid. With the use of the aid instrument the State realizes objectives that are considered a priority for socioeconomic development.

The proposed research thesis in the paper, according to which, both in relation to the European Union and its individual Member States, State aid in the form of grants and tax subsidies is positively correlated with the size of the general government sector debt, should be rejected. It cannot be considered as true the thesis that with increasing the amount of grants and tax subsidies the EU general government sector debt increases. It was incorrect to assume that this correlation occurs for all Member States, because the amounts spent on State aid in the form of grants and tax subsidies to enterprises are very different at the level of individual Member States. Different is also the proportion of aid actually granted in the aid approved by the European Commission.

\section{References}

Adamkiewicz-Drwiłło H.G., 2010, Konkurencyjność przedsiębiorstw w świetle uwarunkowań współczesnej gospodarki, Towarzystwo Naukowe Organizacji i Kierownictwa, Wydawnictwo "Dom Organizatora", Torun.

Bacon K., 2009, European Community Law of State Aid, Oxford-New York: Oxford University Press.

Bumane I., Vodolagins D., 2017, Favourable tax regimes that constitute selective state aid from the perspective of the cjeu recent case-law, "European Research Studies Journal", Vol. 20, Issue 3.

Biondi A., 2013, State Aid is falling down, falling down: An analysis of the case law on the notion of Aid, "Common Market Law Review", Vol. 50, Issue 6.

Botta M., Schwellnus G., 2015, Enforcing state aid rules in EU candidate countries: a qualitative comparative analysis of the direct and indirect effects of conditionality, "Journal of European Public Policy", Vol. 22, Issue 3.

Botta M., 2016, Competition policy: safeguarding the Commission's competences in State aid control, "Journal of European Integration", Vol. 38, Issue 3. 
Crafts N., 2017, Brexit and State aid, "Oxford Review of Economic Policy", Vol. 33.

Demsetz H., 1969, Information and Efficiency: Another Viewpoint, "Journal of Law and Economics", Vol. 12, No. 1.

European Commission 2001 Ninth Survey on State Aid in the European Union, Brussels 18.07.2001, COM(2001) 403 final.

Eurostat, 2018a, State aid in the form of grants, electronic document, access mode: [http://ec.europa.eu/eurostat/tgm_comp/refreshTableAction.do;jsessionid $=$ RHg7FyAhwmbn-FmSfphghPCjLVAAyFDyUUytVsDXmxT28eUL9E1x!-1 003025192 ?tab=table\&plugin $=1 \&$ pcode $=$ comp_ai_sa_01\&language $=e n$, date of entry: 10.03.2018].

Eurostat, 2018b, State aid in the forms of tax exemptions and tax deferrals, electronic document, access mode: [http://ec.europa.eu/eurostat/tgm_comp/refresh TableAction.do? tab=table\&plugin $=1 \&$ pcode $=$ comp_ai_sa_01\&language $=e n$, date of entry: 10.03.2018].

Godłów-Legiędź J., 2005, Główny nurt wspótczesnej ekonomii: od formalizmu do nowego instytucjonalizmu, [w:] Historia myśli ekonomicznej, Landreth $\mathrm{H}$., Colander D.C., Wydawnictwo Naukowe PWN, Warszawa.

Maurici J., Sargent H., 2015, State aid in planning and compulsory purchase order cases, "Journal of Planning and Environmental Law", Issue 6.

Micheau C., 2015, Tax selectivity in European Law of State Aid: Legal assessment and alternative approaches, "European Law Review", Vol. 40, Issue 3.

Milhet A.M., 2017, Are european state aid payments creditable Foreign taxes?, "Georgetown Law Journal", Vol. 105, Issue 5.

Nicolaides P., 2004, Fiscal State Aid in the EU: The Limits of Tax Autonomy, "World Competition", Vol. 27, Issue 3.

Nicolaides P., 2013, Competition and advantage under internal market and state aid rules: Is there a gap in the law?, "Legal Issues of Economic Integration", Vol. 40, Issue 3.

Nicolaides P., Metaxas A., 2014, Asymmetric Tax Measures and EU State Aid Law, "European State Aid Law Quarterly", Vol. 13, Issue 1.

Nicolaides P., 2015, A critical analysis of reductions from environmental taxes in the new guidelines on state aid for environmental protection and energy, 2014-2020, "Energy and Environment", Vol. 26, Issue 4.

Owsiak S., 2006, Finanse publiczne. Teoria i praktyka, Wydawnictwo Naukowe PWN, Warszawa.

Pisapia A., 2015, The role of EU state aid policy in enhancing the development of the industrial sector, "Privredna Kretanja i Ekonomska Polityka", Vol. 23, Issue 123.

Podsiadło P., 2015, Tax Subsidies and State Aid in the European Union, "Argumenta Oeconomica Cracoviensia", No. 12, DOI: 10.15678/AOC.2015.1208.

Podsiadło P., 2016, Regional State Aid and Its Impact on the Competitiveness of the EU Member States, "International Conference on European Integration", Ostrava: VŠB-TU Ostrava, Faculty of Economics. 
Treaty on the Functioning of the European Union (TFEU), Consolidated version 2016, OJ C 202/47.

Tunali Ç.B., Fidrmuc J., 2015, State Aid Policy in the European Union, "Journal of Common Market Studies", Vol. 53, Issue 5.

Veebel V., Ploom I. and Kulu L., 2015, Shortcomings of the EU state aid model from peripheral perspective: The case of Estonian Air, "Baltic Journal of Economics", Vol. 15, Issue 1. 